\title{
Drought mitigation participatory at Pinang Luar Lowland, West Borneo (Indonesia)
}

\author{
Henny Herawati ${ }^{1, *}$, Stefanus B.Soeryamassoeka ${ }^{1}$ \\ ${ }^{1}$ Civil Engineering Department, Tanjungpura University, 78124 Pontianak, Indonesia
}

\begin{abstract}
Indonesia is a tropical country with 2 seasons, the rainy season and the dry season. In the rainy season, flood can occur causing a disaster due to excess water. But in the dry season it happens to prolonged drought cannot fulfilll the society needs as decent life. In the areas of the downstream of Kapuas River, the impact of the drought is the intrusion salinity. Where as agricultural land as Pinang Luar lowland agitated of drought that leads to crop failure. This study will be conducted by qualitative descriptive analysis of survey results at Kapuas downstream area which is Pinang Luar tidal lowland. As the result of this research is mitigation of drought can be made bycommunity participatory. For agricultural cultivation, the community has to get involved in some activities such as: (1) conservation ofland and water (2) maintain the irrigation network (3) developing water-saving agriculture, and (4) setting the cropping pattern. And for the mitigation efforts in participatory forest fires can be done by making the channels controlling groundwater levels. To complying the water needs of the community in the dry season can be solve by rain storage ponds, so that the stored water can be used in drought times.
\end{abstract}

\section{Introduction}

Indonesia is a tropical country with 2 seasons, the rainy and the dry season. The seasons do not always occur in the same month every year. Similarly, the amount of water available. The water available is determined by the amount of rainfall that occurred. That was not always happened the same amount of rainfall every season [1]. West Kalimantan is one of provinces in Indonesia that located on the equator line with significant water resources, the average annual rainfall reaches 2,500-3,000 $\mathrm{mm}$ almost around this region butWest Kalimantan have experienced excess water and water supply shortage.

Kapuas River is the longest river in Indonesia that located in West Kalimantan. During the rainy season flooding can occur that spread everywhere, especially on the residential areas, roads and the agriculture areas. All human activity and productivity do not run properly.

However in the dry season the opposite occurs, prolonged drought can not fulfill clean water, water available for agriculture, plantation and fishery. The impact of drought, cause the forest fire, andsalinity intrusion in the zone that located in the lower part (near the Kapuas River estuary such as Pontianak City).

Pinang Luar is one of the areas that was developed as agricultural land is in the Kapuas River estuary. Pinang Luar area is an area that affected by tides. In the rainy season, agricultural land in area of Pinang Luar have waterlogging. Whereas in the dry season the area is experiencing drought and crop failure, and in certain circumstances can cause forest fires.

With optimal tidal lowland water management the area will produce high agricultural production [2]. The amount and distribution of rainfall in the rainy season which is enough for one growing season will give high agricultural production with proper water management [2]. Potential rainfall around the tidal lowlandof Pinang Luar is very high. The average annual rainfall reaches $3,000 \mathrm{~mm}$ and the average monthly rainfall reaches 250 $\mathrm{mm}$ [3]. The amount of monthly precipitation with a probability of $80 \%$ greater than the evapotranspiration that occurs in a year (except in February and August) [3].

Based on the description above, in the area of West Kalimantan in general potentially have excessed water during the rainy season and otherwise have drynessed in the dry season. The tidal lowlandof Pinang Luar is an area that was developed as one of land for cultivation. But as an area that affected by tides, that potential is not always reliable to irrigate agricultural land in Pinang Luar, because the availability of water also affected by the rainy season and the dry season. Problems that have been created by all of aspects above, therefore, it is necessary to analysis how to anticipate the water excess and how prevention (mitigation) dryness in tidal lowlandof Pinang Luar.

This paper have purposed to identify the potential of water in tidal lowlandof Pinang Luar and determined the concept of drought mitigation. This research needs to determine the efforts to mitigate drought in this area, so

*Corresponding author: hennyherawati@civil.untan.ac.id 
the water can be provided as needed, as a basic need for people and for the agriculture.

\section{Methodology and study area}

The study was conducted in tidal lowlandof Pinang Luar. Geographically, Pinang Luar is at $0^{\circ} 16^{\prime}-0^{\circ} 18^{\prime}$ South Latitude and $109^{\circ} 18^{\prime}-109^{\circ} 23^{\prime}$ East Latitude. This area is located at Kapuas River estuary and periodically influenced by tides. Land elevation in Pinang Luar area is relative flat that is $1-3.5 \mathrm{~m}$ (refer to the MSL). This area was developed as an agricultural cultivation area for the community. Local communities take advantage of the movement of the tide to fulfill their water needs.

This study will be conducted by qualitative descriptive analysis of field survey results. The datas are secondary and primary data which can be describe the potential, constraints and existing problems in tidal lowland of Pinang Luar. Secondary data consist of rainfall data and topographic data. The data of rainfall obtained from the closest station to the study area, BMKG Station Supadio Pontianak. Land conditions and channel system in tidal lowlandof Pinang Luar can be seen in Figure 1.

Primary data is a tidal measurement data in the study area. Tidal observations conducted at the Kapuas River, thetidal lowland of Pinang Luar for 15 days, taken byobservations on April 15 to 28, 2014.

Land elevation displayed in contour map of ground surface elevation. By using the Global Mapper Software v.17.0, the water fluctuation and groundelevation will be analysis. The overlay of tidal measurement data and land elevation, can be describe the changing of inundation level when the water level in highest and the lowest oftides. The next step is finding the location of rainfall water storage (pond) that can be built for drought mitigation.

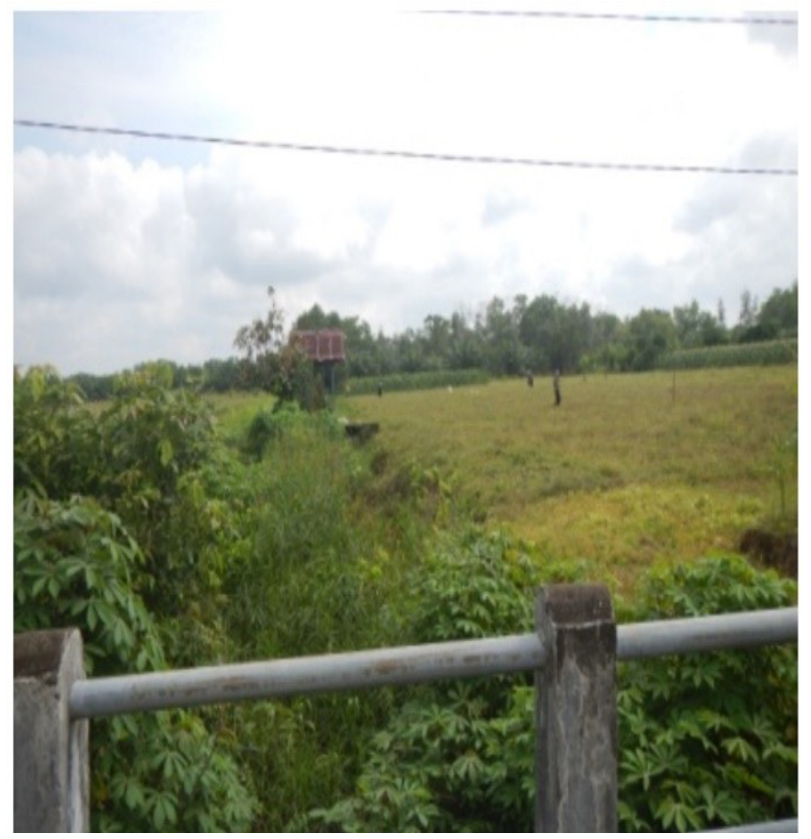

(a) Tertiary channels filled with sediment and grass

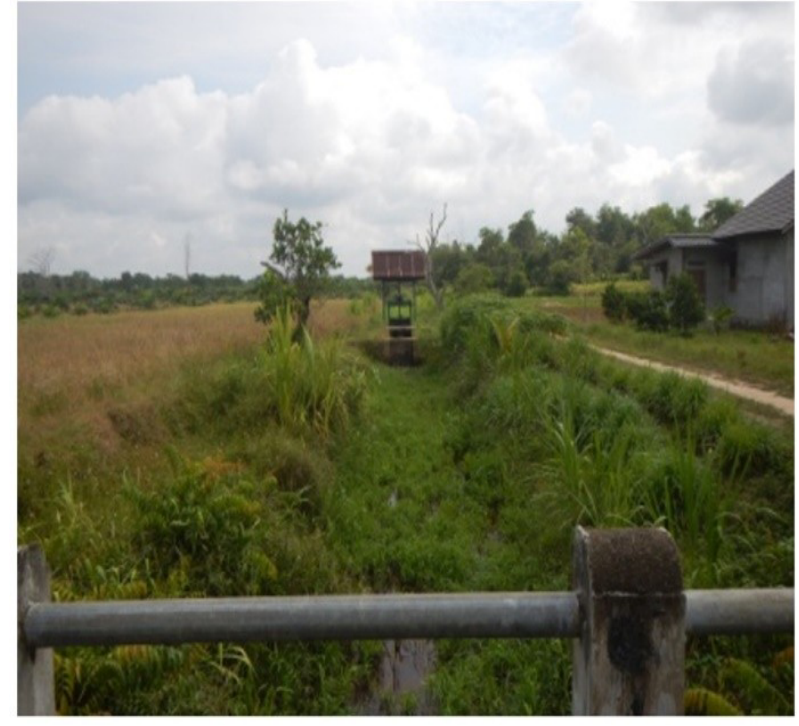

(b) The control gates are not functioning

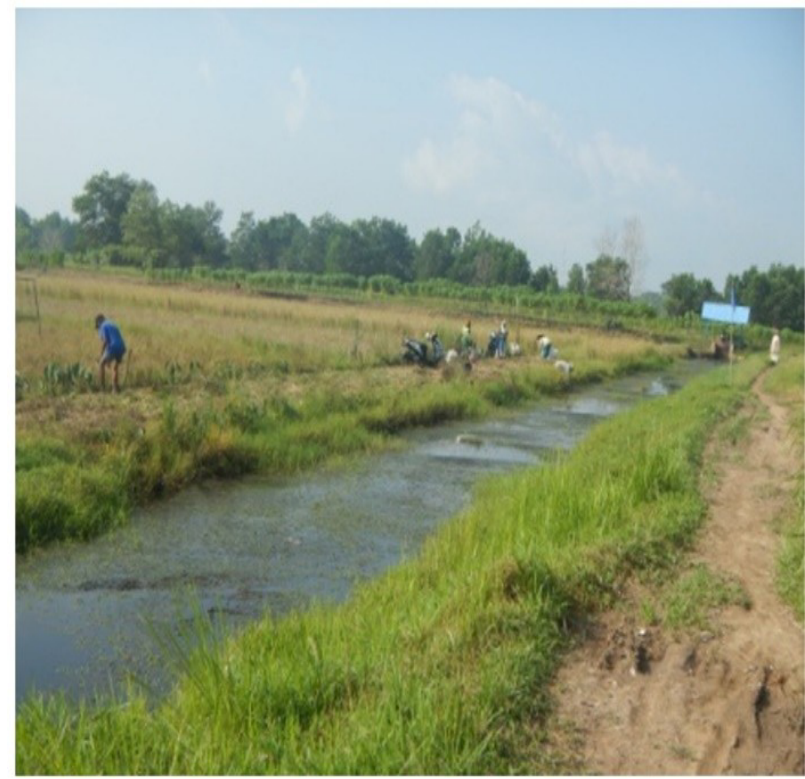

(c) Channel tertiary treated by society in a participatory manner

Fig. 1. Land conditions and channels in tidal lowlandof Pinang Luar

\section{Result and discussion}

\subsection{Rainfall potential in study area}

The research area is located at Kapuas River estuary. Kapuas River estuary is a lowland areas that are affected by tides. The study area elevation ranges from 1-3.5 m (refer to the MSL). This causes the water level can not reach land, both during neap tides and spring. So,the paddy cultivation can only be done on a small portion in Pinang Luar, and can only be planted once a year. Because the water level is not enough to irrigate the land, the land was allocated to plant paddy replaced by crops. And in some other parts, changed as oil palm plantations. 
Based on rainfall data in BMKG Supadio Station,years 1970-2015 describe the potential of rainfall in the study area is high, with an average of 3,130 mm.year ${ }^{-1}$ or an average of $261 \mathrm{~mm} . \mathrm{month}^{-1}$. The amount of rainfall that occurred during the last 45 years tend to decrease. This can be seen in Figure 2. The number of days of rain events tend to decrease that resulted in the drought tends to rise. This condition is not favorable for the farmers to make the cultivation of agriculture [1].

\subsection{Tidal potential in study area}

From the observation and forecasting, the elevation tides that occur in Pinang Luar area is $152 \mathrm{~cm}$, the important value elevations of subsequent observations made forecasting as shown in Table 1. Elevation's tidal effect on the availability of water in Pinang Luar area. By using the tidal water movement in the Kapuas River, water can irrigate Pinang Luar agriculture area. This can occur onrainy season.

The hydro-topographical conditions in the tidal lowlands as the starting point for the analysis of land suitability is determined from ground elevation than the elevation of the river or canal. From the analysis of the high tides that occur, in generally Pinang Luar never have water logged 4-5 times during one tide cycle, both spring and neap tides are referred to as hidrotopography A. In the rainy season and the highest tide only a few parts which overflow. At low tide conditions, water can only reach the channel. This will worsen the dry season. Comparison of water level and overflow areas in Pinang
Luar can be seen in Figures 3 and 4. The map is based on the water level of the Kapuas River in Pinang Luar, precisely located in the intake of primary channel. Discharge from upstream assumed in normal condition.

In the dry season, the discharge from upstream is decrease. The impact is fresh water that flows to downstream also decrease. So the water level in of Pinang Luar is also decrease, especially at low tide conditions. Water will drainfrom the channels ofPinang Luar water management network system. If the management do not control the water level, in the dry season will occur over drain in the channel. Suppletion water will be decreaseand ground water at low tide will be ran out into the channel. It is critical for the occurrence of forest fires.

Table 1. Important tidal water level elevation observations at Pinang Luar.

\begin{tabular}{|l|l|c|}
\hline \multicolumn{1}{|c|}{ Name } & \multicolumn{1}{|c|}{ Simbol } & Elevation (m) \\
\hline Highest Water Spring & HWS & 0.80 \\
\hline Mean High Water Spring & MHWS & 0.65 \\
\hline Mean High Water Level & MHWL & 0.33 \\
\hline Mean Sea Level & MSL & .00 \\
\hline Mean Low Water Level & MLWL & -0.32 \\
\hline Mean Low Water Spring & MLWS & -0.62 \\
\hline Lowest Water Spring & LWS & -0.72 \\
\hline
\end{tabular}

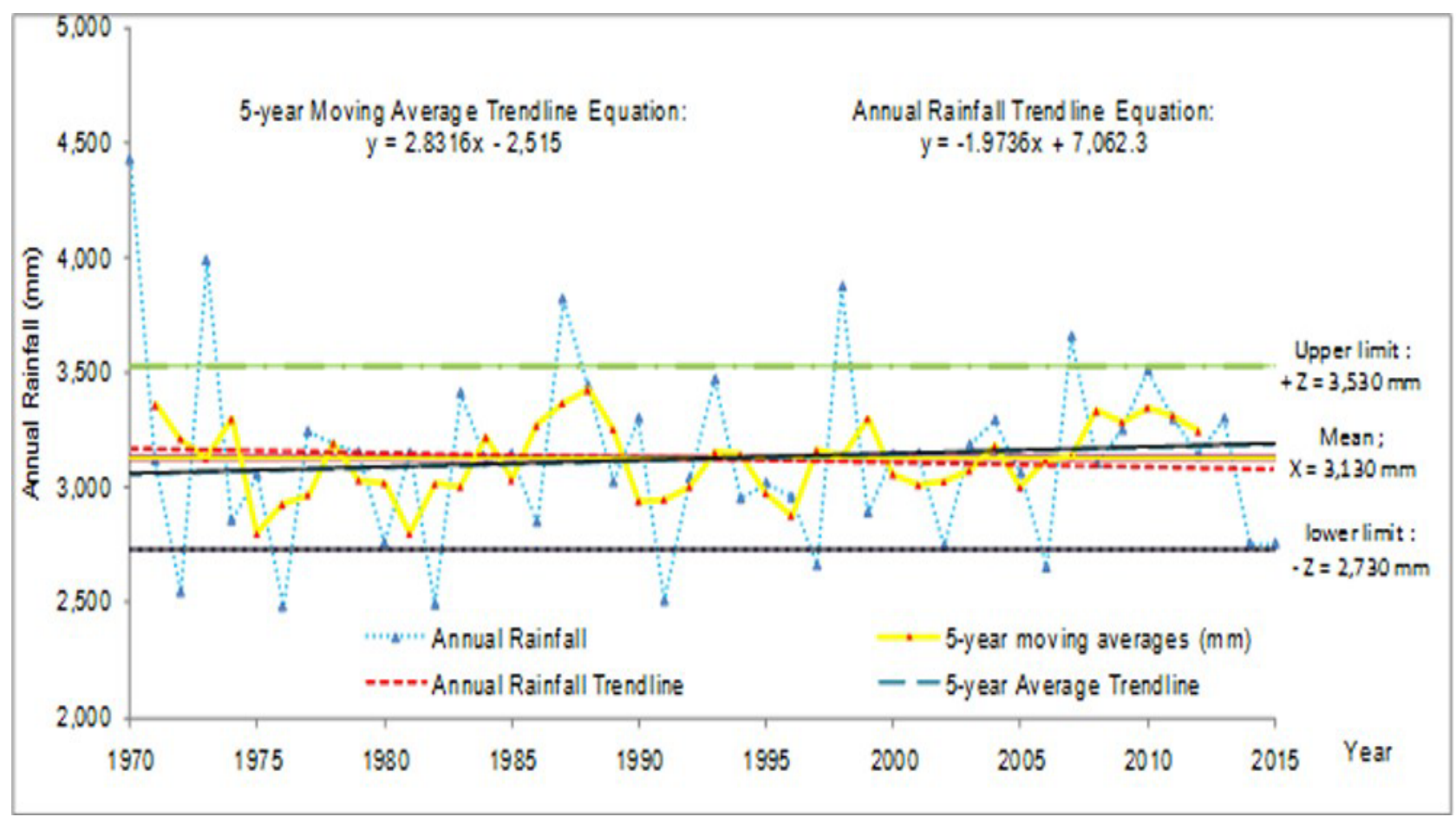

Fig.2. The annual rainfall for 45 years (1970-2015), BMKG Stations Supadio, Pontianak [1,4] 


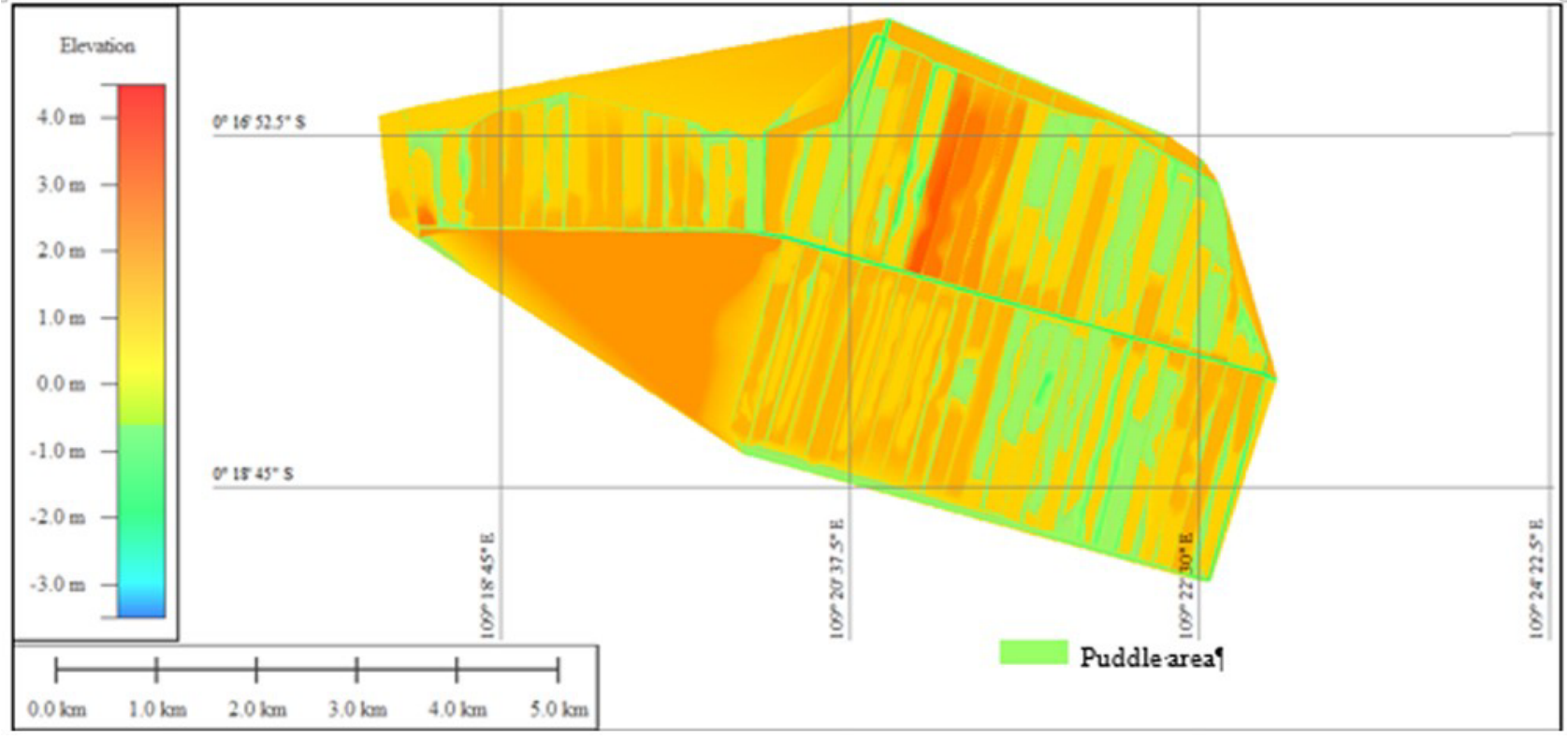

Fig. 3. The land surface elevation and a puddle due to the influence of the highest water spring level (HWS) is 0.8 meters at the Kapuas River estuary

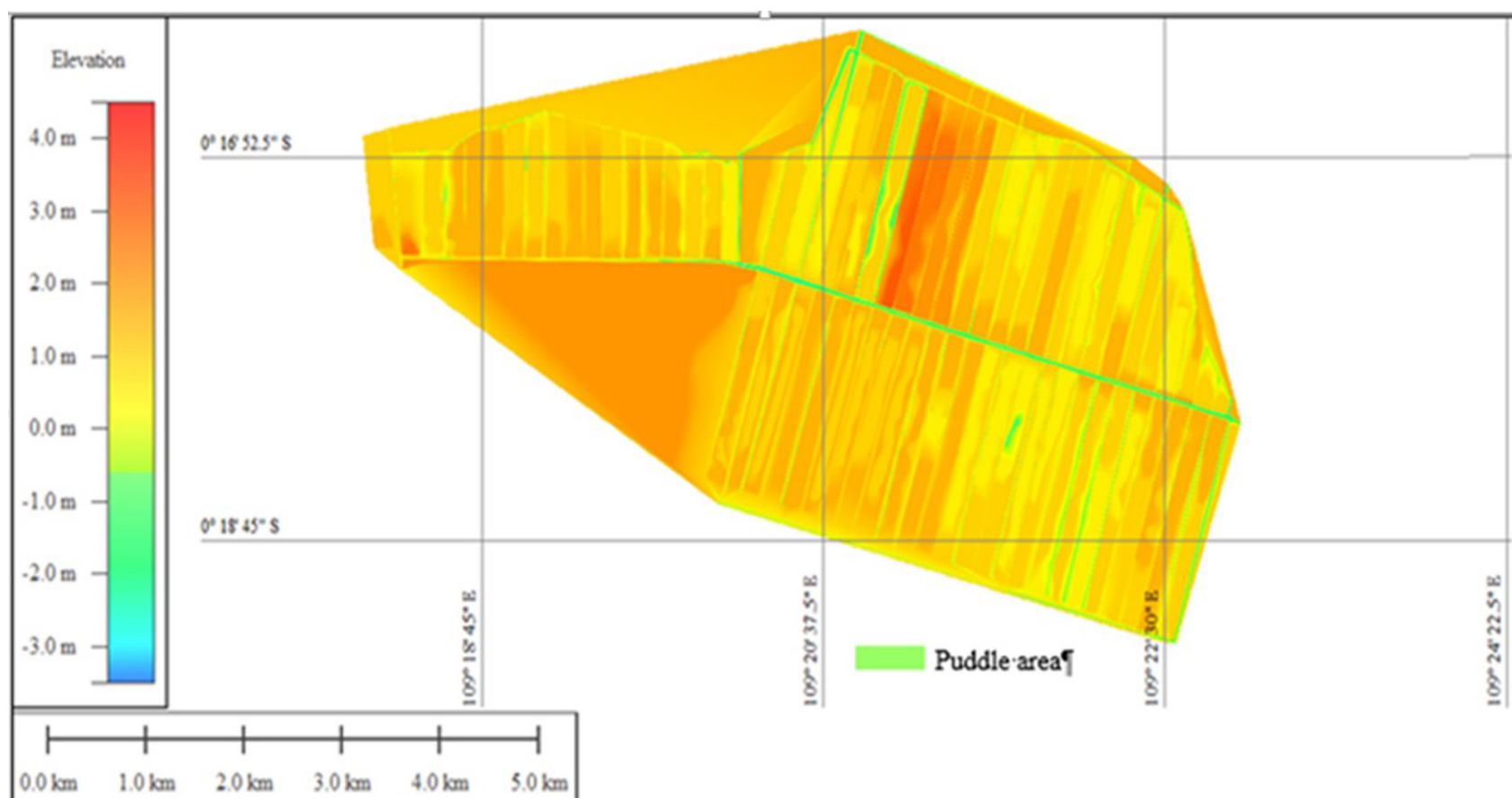

Fig. 4. The land surface elevation and puddle due to the influence of lowest water spring (LWS) level is -0.72 meters at the Kapuas River estuary

\section{Constraints on the field}

Research area already constructed network system of water tidal management. If the facility of water system is functioning properly, the water management system can be set optimally so the plants can be grown with high productivity. Operations and maintenance will support the efforts of agricultural cultivation. Based on the observations, the availablity offacilities have not been fully utilized. This can be seen in Figure 1. Many channels are not well maintained. Tertiary channel capacity is reduced due to a lot of sediment and vegetation in the middle of the channel which makes the shallow ofchannel.

In the Pinang Luar consists of the primary channel, secondary channels and tertiary channels. At each end of the tertiary channels equipped with sluice gates. Based on the observations, the control gates have not functioned well to control the water level. Then, the flat area will be difficult to release the water to the network system. The discharge is highly depend on the Kapuas Riverwater level, which also detracted from the tide.

Moreover the operation and maintenance have not been apply, Pinang Luar have not storage and freshwater reservoir. Fresh water depend on rainfall and the tides 
from Kapuas River. Therefore, when water gets into the channel will be ran out into the river at low tide. As low land area, Pinang Luar area is a marshland that has a high void ratio: $0.6-0.7$. So the ability to store water is poor when the ground water level is low.

\section{Mitigation efforts}

Water management strategies should be focus on maintaining the ground water level at the appropriate level for soil, water, hydro-topography conditions and land use $[2,5,6]$. Water management strategy aims to fulfill the water needs of plants although for community. In addition management strategy is also intended to reduce the adverse effects on the environment [7]. Wetlands can be used as a source of irrigation water [8].

One of the constraint is no infrastructure which can savethe fresh water. The fresh water from rainfall and the tides wasted through the channel. With the potential rainfall and soil conditions, Pinang Luar is very needed to build a pond as a water reservoir to fulfill the irrigation needs.

Based on the analysis of Pinang Luar, drought mitigation and land as well as to prevent forest fires can be done various efforts. The effort is a way to control the availability of water through the control of water level in the soil and in the channel. The efforts are:

1. Provide knowledge of ideal water level in the channel and on the land to farmers.

2. Assign or provide operational and maintenance jobs to farmers in a participatory manner.

3. Performs the channel utilization as control water levels on the farm.

4. Install the door controllers to the tertiarychannels or quarter which directly flow to the land.

5. Make some ponds as water reservoir.

The efforts to control the groundwater table above can be done by the participation of community. By the team work called gotong royong (mutual aid society), has ability to perform operations and maintenance and optimal control. Community involved to clean the channel(Figure 1 (c)). So the channel can function optimally. Channels that function well, will be as long storage to reserves of water that can be used at low tide conditions.

Ponds/storages construction can be built on the land with the elevation above $3 \mathrm{~m}$ as shown in Figures 3 and 4. At high tide the water will be flow into ponds and when the low tide the doors will be close. So the water will be collected in ponds. Stored water will be release when the water in channelsis less to fulfill the water needs for irrigation.

To increase the agricultural production, the appropriate cropping patterns is needed and the selection of adaptive seeds with tidal land. If these attempts to do so will increase agricultural productivity. Based on field data, the paddy productivity about 2 ton.hectare ${ }^{-1}$. Most of agricultural land still dependent to rainfall.

\section{Conclusion}

Based on the results of this study concluded that drought mitigation efforts can be done in a participatory manner, the role of the community actively to mitigate the drought. Drought mitigation can control the water level in the channel and land. Controling of water level aims to set the level of the water table to fit the needs of the plant. Good control of water level also can prevent land dryness as to prevent the forest fires and can improve the quality of the land for agriculture. Mitigation measures are participatory forest fires can be done by controlling groundwater levels.

For agricultural cultivation, the community has to get involved in some activities such as: (1) conservation of land and water (2) maintain the irrigation network (3) developing water-saving agriculture, and (4) setting the cropping pattern. To fulfill the needs of household water in the dry season can made ponds rain reservoir, so the stored water can be used in times of drought. In addition to rainwater, ponds also can store fresh water into the channel at high tide. And shut the door controllers at low tide, so the water will not be wasted during low tide.Creating a rainfall reservoir ponds is a new concept in the area of tidal marshto address the needs of irrigation water.

This research was conducted with financial support to authors through Fundamental Research financed by the Directorate General of Higher Education Ministry of Research Technology and Higher Education through a grant letter of number 0299/E3/2016 dated January 27th, 2016. The authors would like to thank to the reviewersfor the valuable comments and suggestions in order to improve the quality of the paper.

\section{References}

1. Agency of Meteorology, Data Curah Hujan Stasiun Supadio Pontianak, Pontianak Clim. and Geoph., (2016)

2. H. Herawati, Suripin. Suharyanto. Procedia Engineering 125, 185-192 (2015)

3. F. X. Suryadi, Soil and Water Management Strategies for Tidal Lowlands in Indonesia, Netherlands (1996)

4. H. Herawati, IRJES 4, Issue 9, 01-06 (2015)

5. F.X. Suryadi, E. Schultz, Proc.Workshop on the Agricl. Based Dev. of Tidal Swamps and Estuaries and Env. Cons. Seoul-Korea, (2001)

6. M. S. Imanudin, E. Armanto, R. H. Susanto, S. M. Bernas, J. Trop Soils 15, No. 3, 277-282 (2010)

7. S.K. Hong, C.H. Koh, R. R. Harris, J.E. Kim, J.S. Lee, B.S. Ihm, Land Use in Korean Tidal Wetlands: Impacts and Mgt Strategies, Env. Mgt 45, 10141026 (2010).

8. Y. Wang, Y. Yao, M. Ju, Wise Use of Wetlands: Current State of Prot. and Utilz. of Chinese Wetlands and Rec. for Impr., Env. Mgt 41, 793-808 (2008). 